\title{
Simple Cocasting Method to Prepare Magnetic Mesoporous FePt/C Composites and Their Protein Adsorption Property
}

\author{
Yufang Zhu and Xing He \\ School of Materials Science and Engineering, University of Shanghai for Science and Technology, 516 Jungong Road, \\ Shanghai 200093, China \\ Correspondence should be addressed to Yufang Zhu; yfzhu@usst.edu.cn
}

Received 11 June 2012; Accepted 19 August 2012

Academic Editor: Renal Backov

Copyright ( $\odot 2013$ Y. Zhu and X. He. This is an open access article distributed under the Creative Commons Attribution License, which permits unrestricted use, distribution, and reproduction in any medium, provided the original work is properly cited.

\begin{abstract}
A simple cocasting method has been developed to prepare magnetic mesoporous $\mathrm{FePt} / \mathrm{C}$ composites with superparamagnetic $\mathrm{FePt}$ nanoparticles embedded in carbon walls. Furfuryl alcohol, iron(III) acetylacetonate ( $\mathrm{Fe}(\mathrm{acac})_{3}$ ), and platinum(II) acetylacetonate $\left(\mathrm{Pt}(\mathrm{acac})_{2}\right)$ were used as the carbon and FePt nanoparticle precursors to be simultaneously incorporated into the channels of mesoporous silica SBA-15 template by the incipient wetness impregnation technique. After the polymerization of furfuryl alcohol, the carbonization in argon, and the removal of silica template, magnetic mesoporous $\mathrm{FePt} / \mathrm{C}$ composites were finally obtained. Magnetic mesoporous FePt/C composites have high surface area of $1244 \mathrm{~m}^{2} / \mathrm{g}$ and narrow mesopore size distribution peaked at $4.93 \mathrm{~nm}$. FePt nanoparticles were well embedded in mesoporous carbon walls, and mesoporous FePt/C composites exhibit superparamagnetic behavior. Using cytochrome c (Cyt c), myoglobin (Mb), and bovine serum albumin (BSA) as model proteins, the adsorption capacities of Cyt c, Mb, and BSA on magnetic mesoporous FePt/C composites can reach ca. 200, 162, and 121 $\mu \mathrm{g} / \mathrm{mg}$, respectively. These results indicated that mesoporous $\mathrm{FePt} / \mathrm{C}$ composites have potential as magnetically separable adsorbent for biomolecules separation.
\end{abstract}

\section{Introduction}

Ordered mesoporous carbon (OMC) materials are of great interest due to their uniform pore structure, high surface area, thermal stability, electrical conductivity, chemical inertness, biocompatibility, and specific surface properties $[1,2]$. To date, OMC materials have been widely investigated in various applications, such as adsorption, separation, catalysis, energy storage, and biomedical engineering [3-7]. For example, in medical and food industries, OMC materials could be used as the adsorbents to remove adsorbed proteins from the products solutions; those may give rise to the subsequent adsorption of fibrous proteins leading to adverse biological consequences $[8,9]$. However, mesoporous carbons are notoriously difficult to separate from solutions, especially for mesoporous carbons with small particle sizes, which cause some problems in practical applications.

Compared to the conventional and complex filtration/centrifugation procedure, magnetic separation as a promising strategy has been widely accepted due to the fact that it can be easily separated under an applied magnetic field $[10,11]$. Therefore, many efforts have been made to prepare magnetically separable OMC materials using different approaches recently. One route is the "one-pot" blockcopolymer self-assembly strategy associated with a direct carbonization process. For example, Zhai et al. fabricated OMC materials with magnetic frameworks (mesoporous $\gamma$ $\mathrm{Fe}_{2} \mathrm{O}_{3} / \mathrm{C}$ composites) by the self-assembly strategy from resol, ferric citrate, and triblock copolymer F127 [12]. Kang et al. reported one-pot simple synthesis of FePt nanoparticles inside order mesoporous aluminosilicate/carbon composites by using polyisoprene-block-poly(ethylene oxide) (PI$b$-PEO) as a structure-directing agent [13]. However, it is relatively difficult to obtain OMC materials via a surfactant templating strategy owning to the complexity of the carbonstructure evolution, and only several reports are available until now [14-16].

To date, the most effective and popular route to magnetic mesoporous carbon composites is nanocasting strategy by infiltration of an appropriate carbon precursor and metal 
source into the channels of mesoporous silica, followed by polymerization, carbonization, and subsequent removal of the silica framework [17-22]. For example, Lu et al. prepared cobalt nanoparticles deposited on CMK-3 (CoOMC) and successfully applied mesoporous carbon to magnetically separable adsorbent and hydrogenation catalyst supports [17]. But the synthetic procedure for Co-OMC is rather complex, which hampers broad application of the magnetic mesoporous carbon composites, despite its many important characteristics. Wang et al. impregnated simultaneously furfuryl alcohol and metal nitrates (carbon and magnetic particle precursors) into mesoporous silica SBA-15, followed by polymerization, carbonization, and the removal of silica framework to obtain magnetic mesoporous $\mathrm{FeNi} / \mathrm{C}$ composites [18].

However, in some as-synthesized magnetic OMC materials, magnetic nanoparticles, for example, $\mathrm{Fe}_{3} \mathrm{O}_{4}, \gamma-\mathrm{Fe}_{2} \mathrm{O}_{3}$, $\mathrm{Ni}$, are easily subject to oxidation in air or dissolution in acid if no effort has been made to protect magnetic nanoparticles by a carbon-layer coating or embedding in carbon walls. It is well known that FePt nanoparticles have superparamagnetic property and high chemical resistance against acid or oxygen attack [23], which are suitable for adsorption/separation applications. Gupta et al. and Kockrick et al. reported the formation of FePt nanoparticles in mesoporous silica by using the wetness impregnation technique $[24,25]$. Our group has developed a nanocasting route to prepare magnetic OMC materials with FePt nanoparticles, involving the polymerization of the impregnated furfuryl alcohol in the channels of mesoporous silica KIT-6, the repeated wetness impregnation of FePt precursors $\left(\mathrm{Fe}(\mathrm{acac})_{3}\right.$ and $\left.\mathrm{Pt}(\mathrm{acac})_{2}\right)$, the carbonization in argon, and the removal of mesoporous silica templates [26]. Obviously, the repeated wetness impregnation of FePt precursors is a time-consuming process, and it is also difficult to control the uniform distribution of FePt nanoparticles in the whole OMC particles.

In this work, we developed a simple cocasting method to simplify the nanocasting procedure for the preparation of magnetic mesoporous FePt/C composites using mesoporous silica SBA-15 as hard template. Furfuryl alcohol, Fe(acac) ${ }_{3}$, and $\mathrm{Pt}(\mathrm{acac})_{2}$ were simultaneously incorporated into SBA-15 by the wetness impregnation technique, following the polymerization of furfuryl alcohol, the carbonization in argon, and the removal of silica template, magnetic mesoporous FePt/C composites were obtained. This cocasting method makes the procedure simple and saves the preparation time. Furthermore, using Cyt c, Mb, and BSA as model proteins, the adsorption properties of magnetic mesoporous $\mathrm{FePt} / \mathrm{C}$ composites were also investigated.

\section{Experimental}

2.1. Synthesis of Mesoporous Silica SBA-15. Mesoporous silica SBA-15 was prepared following a previously reported method [27]. $4.0 \mathrm{~g}$ of $\mathrm{P} 123\left(\mathrm{EO}_{20} \mathrm{PO}_{70} \mathrm{EO}_{20}\right)$ was added to a mixture of $30 \mathrm{~g}$ of $\mathrm{H}_{2} \mathrm{O}$ and $120 \mathrm{~g}$ of $2 \mathrm{M} \mathrm{HCl}$ aqueous solution in a Teflon-lined container, which was stirred at $35^{\circ} \mathrm{C}$ usually overnight. Then, $8.50 \mathrm{~g}$ of TEOS was added into this solution under vigorous stirring. After 5 min of stirring, the mixture was kept under static conditions at $35^{\circ} \mathrm{C}$ for $20 \mathrm{~h}$, followed by $24 \mathrm{~h}$ at $100^{\circ} \mathrm{C}$. The solid products were collected by filtration, washed with water, dried, and calcined at $550^{\circ} \mathrm{C}$ in air.

\subsection{Preparation of Magnetic Mesoporous FePt/C Compos-} ites. Magnetic mesoporous $\mathrm{FePt} / \mathrm{C}$ composites were prepared using SBA-15 as hard template, furfuryl alcohol as carbon source, $\mathrm{Fe}(\mathrm{acac})_{3}(99.9 \%)$ and $\mathrm{Pt}(\mathrm{acac})_{2}(98 \%)$ as FePt sources. Typically, equimolar amounts $(0.225 \mathrm{mmol})$ of $\mathrm{Fe}(\mathrm{acac})_{3}$ and $\mathrm{Pt}(\mathrm{acac})_{2}$ were dissolved in $4 \mathrm{~mL}$ of chloroform $\left(\mathrm{CHCl}_{3}\right)$ to obtain the $\mathrm{Fe}(\mathrm{acac})_{3} / \mathrm{Pt}(\mathrm{acac})_{2} / \mathrm{CHCl}_{3}$ solution. Subsequently, $1.2 \mathrm{~mL}$ of $\mathrm{Fe}(\mathrm{acac})_{3} / \mathrm{Pt}(\mathrm{acac})_{2} / \mathrm{CHCl}_{3}$ solution, $1.2 \mathrm{~mL}$ of furfuryl alcohol, and a small quantity of oxalic acid were dissolved in $4 \mathrm{~mL}$ of ethanol under stirring to form a mixed solution. This mixed solution was incorporated into $1 \mathrm{~g}$ of SBA-15 by the wetness impregnation technique. After evaporating the ethanol and chloroform and polymerizing furfuryl alcohol at $100^{\circ} \mathrm{C}$ for $5 \mathrm{~h}$ and at $150^{\circ} \mathrm{C}$ for $2 \mathrm{~h}$, the resulting composites were thermal treated in argon at $700^{\circ} \mathrm{C}$ to carbonize the polyfurfuryl alcohol and induce the formation of FePt nanoparticles. The silica templates in the composites were removed by twice washing with heated $2 \mathrm{M} \mathrm{NaOH}$ solution. The template-free mesoporous FePt/C composites were collected by filtering, washed with water and ethanol, and dried at $100^{\circ} \mathrm{C}$.

2.3. Characterization. The wide angle X-ray diffraction (WAXRD) patterns were obtained on a Stoe Stadi P powder diffractometer equipped with a curved germanium (111) monochromator and linear PSD using $\mathrm{Cu} \mathrm{K} \alpha \alpha_{1}$ radiation (1.5405 $\AA$ ) in transmission geometry. The small angle X-ray diffraction (SAXRD) patterns were measured on a Bruker AXS Nanostar using CuK $\alpha$ radiation $(1.5405 \AA)$ and $105 \mathrm{~cm}$ of sample to detector distance. Scanning electron microscopy (SEM) was carried out with a Zeiss DMS 982 Gemini field emission scanning electron microscope. Transmission electron microscopy (TEM) was performed using a JEM-2000FX electron microscope operated at an acceleration voltage of $200 \mathrm{kV} . \mathrm{N}_{2}$ adsorption-desorption isotherms were obtained on a Nova 2000 pore analyzer at $77 \mathrm{~K}$ under continuous adsorption conditions. BET and $\mathrm{BJH}$ analyses were used to determine the surface area, pore size, and pore volume. UV/Vis adsorption measurements were recorded using a Shimadzu UV-2450 spectrophotometer. Magnetic measurement was carried out on a superconducting quantum interference device (SQUID) magnetometer at room temperature.

\subsection{Adsorption of Proteins on Magnetic Mesoporous FePt/C} Composites. A series of protein solutions (Cyt c, Mb, and BSA) with concentrations ranging from $0.05 \mathrm{mg} / \mathrm{mL}$ to $2 \mathrm{mg} / \mathrm{mL}$ were prepared by dissolving each protein in buffer solutions with different $\mathrm{pH}$ values ( $\mathrm{pH} 3.6 \sim 10.8)$. In a typical adsorption experiment, $20 \mathrm{mg}$ of magnetic mesoporous $\mathrm{FePt} / \mathrm{C}$ composites was suspended in $10 \mathrm{~mL}$ of protein solution in a closed vial, and the resulting mixture was shaken at $4^{\circ} \mathrm{C}$ and $120 \mathrm{rpm}$ for $72 \mathrm{~h}$ to reach the equilibration of protein adsorption. The amount of protein adsorbed was calculated 


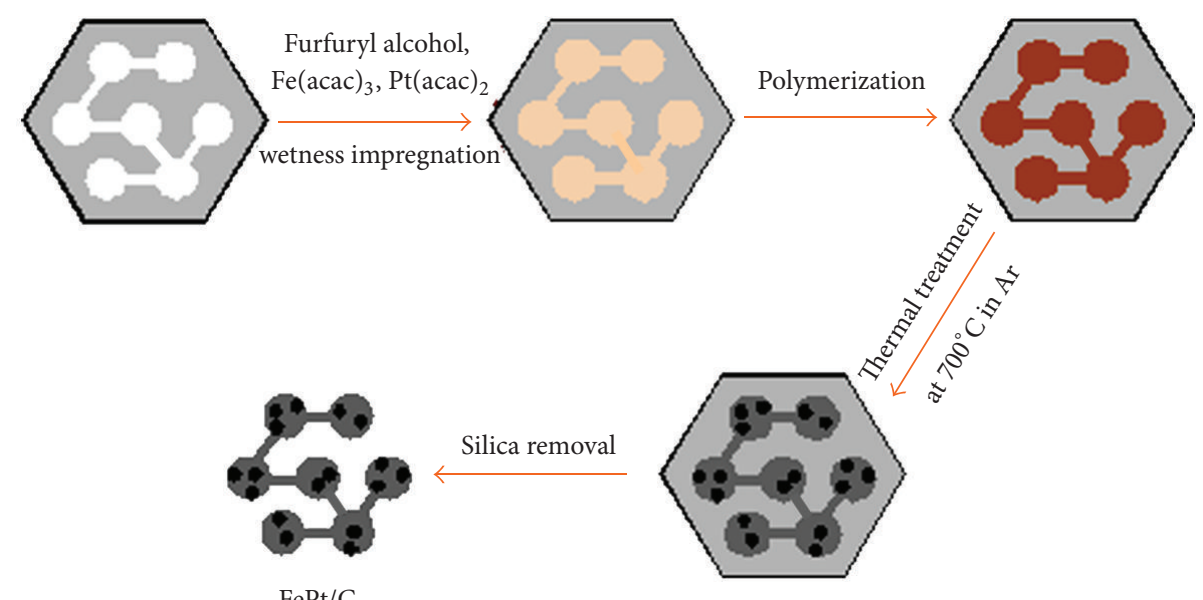

FIGURE 1: Schematic procedures for the synthesis of magnetic mesoporous FePt/C composites.

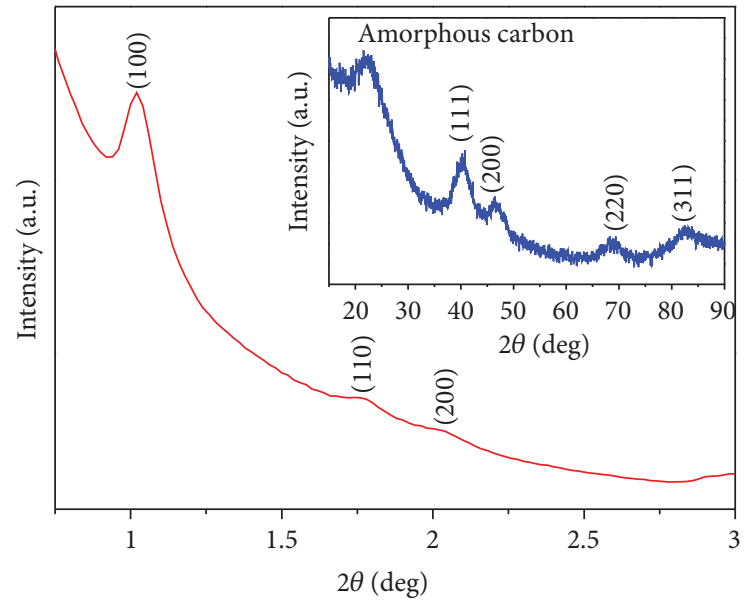

FIGURE 2: Small-angle XRD pattern of magnetic mesoporous FePt/C composites, and the inset is wide-angle XRD pattern of magnetic mesoporous FePt/C composites.

by subtracting the amount found in the supernatant liquid after adsorption from the amount of protein present before the addition of the adsorbent by UV analysis at a certain wavelength (Cyt c at $407 \mathrm{~nm}, \mathrm{Mb}$ at $409 \mathrm{~nm}$, and BSA at $279 \mathrm{~nm}$, resp.). Calibration experiments were done separately before each set of measurements with protein solutions of different concentrations buffered at the same $\mathrm{pH}$ as the isotherm. Magnetic separation prior to the analysis was used to avoid potential interference from the suspended scattering particles in the UV-Vis analysis.

\section{Results and Discussion}

Figure 1 illustrates the schematic procedure used in this work for the synthesis of magnetic mesoporous $\mathrm{FePt} / \mathrm{C}$ composites. Firstly, after the calcination to remove the surfactant template from SBA-15, furfuryl alcohol, $\mathrm{Fe}(\mathrm{acac})_{3}, \mathrm{Pt}(\mathrm{acac})_{2}$, and a small quantity of oxalic acid were introduced into the mesoporous channels of SBA- 15 by wetness impregnation technique. Subsequently, furfuryl alcohol was polymerized under the catalysis by oxalic acid to form polyfurfuryl alcohol. During polymerization of furfuryl alcohol, $\mathrm{Fe}(\mathrm{acac})_{3}$ and $\mathrm{Pt}(\mathrm{acac})_{2}$ were embedded in the framework of polyfurfuryl alcohol. Then, polyfurfuryl alcohol was carbonized under Ar atmosphere at $700^{\circ} \mathrm{C}$ to convert into compact carbon, and $\mathrm{Fe}(\mathrm{acac})_{3}$ and $\mathrm{Pt}(\mathrm{acac})_{2}$ were decomposed and in situ carbothermally reduced to magnetic alloy FePt nanoparticles accompanying the carbonization process. Finally, magnetic mesoporous $\mathrm{FePt} / \mathrm{C}$ composites were obtained after the removal of silica template by hot $2 \mathrm{M} \mathrm{NaOH}$ aqueous solution.

Figure 2 shows XRD patterns of magnetic mesoporous $\mathrm{FePt} / \mathrm{C}$ composites. Magnetic mesoporous FePt/C composites exhibit three well-resolved reflections in the $2 \theta$ range between 1 and $2.5^{\circ}$, which can be indexed as (100), (110), and (200) reflections associated with hexagonal symmetry and confirmed the ordered mesoporous structure. The wide-angle XRD pattern of magnetic mesoporous $\mathrm{FePt} / \mathrm{C}$ composites (in the inset of Figure 2) can be easily indexed to amorphous carbon and cubic FePt (JCPDS 29-0717) according to the reflection peak positions and relative intensities, suggesting that FePt has been formed by using carbonization of polyfurfuryl alcohol/SBA-15 containing $\mathrm{Fe}(\mathrm{acac})_{3}$ and $\mathrm{Pt}(\mathrm{acac})_{2}$. Furthermore, the weak and broad FePt characteristic diffraction peaks indicate that the nanoscale FePt particles were formed in the carbon matrix.

Figure 3 shows the representative SEM and TEM images of magnetic mesoporous $\mathrm{FePt} / \mathrm{C}$ composites. From SEM image (Figure 3(a)), magnetic mesoporous $\mathrm{FePt} / \mathrm{C}$ composites are rod-like with the length of ca. $1.0 \mu \mathrm{m}$, which is similar with the morphology of SBA-15 template (not shown). TEM was used to directly observe pore structure and the distribution of FePt nanoparticles in magnetic mesoporous $\mathrm{FePt} / \mathrm{C}$ composites. In TEM image (Figure 3(b)), ordered stripe-like and hexagonally arranged pattern was clearly observed, further confirming the ordered mesostructure of $\mathrm{FePt} / \mathrm{C}$ composites. It can also be seen that a lot of small 


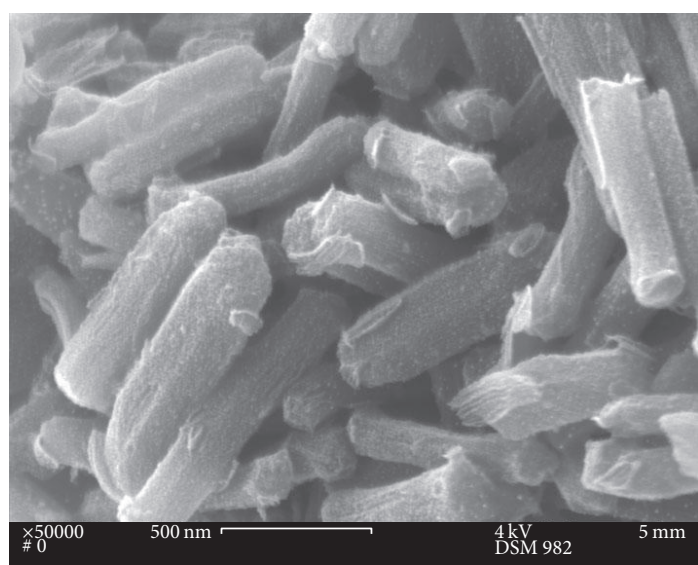

(a)

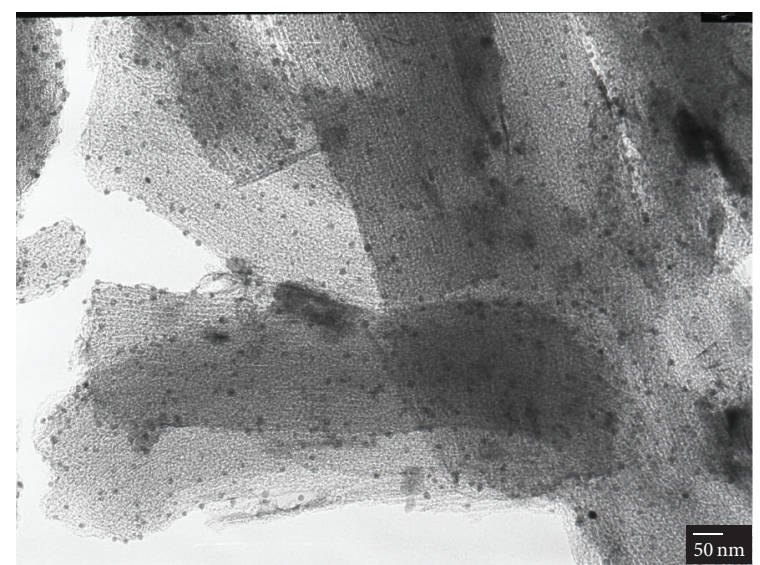

(b)

FIgURE 3: (a) SEM and (b) TEM images of magnetic mesoporous FePt/C composites (scale bar in (a): $500 \mathrm{~nm}$; scale bar in (b): $50 \mathrm{~nm}$ ).

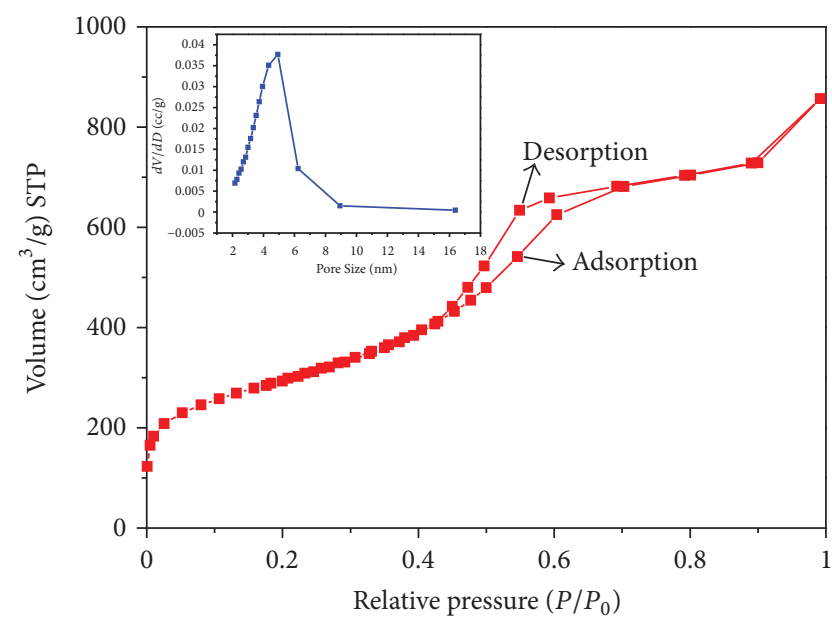

FIGURE 4: Nitrogen adsorption-desorption isotherm of magnetic mesoporous $\mathrm{FePt} / \mathrm{C}$ composites and the corresponding pore size distribution calculated from the desorption branche.

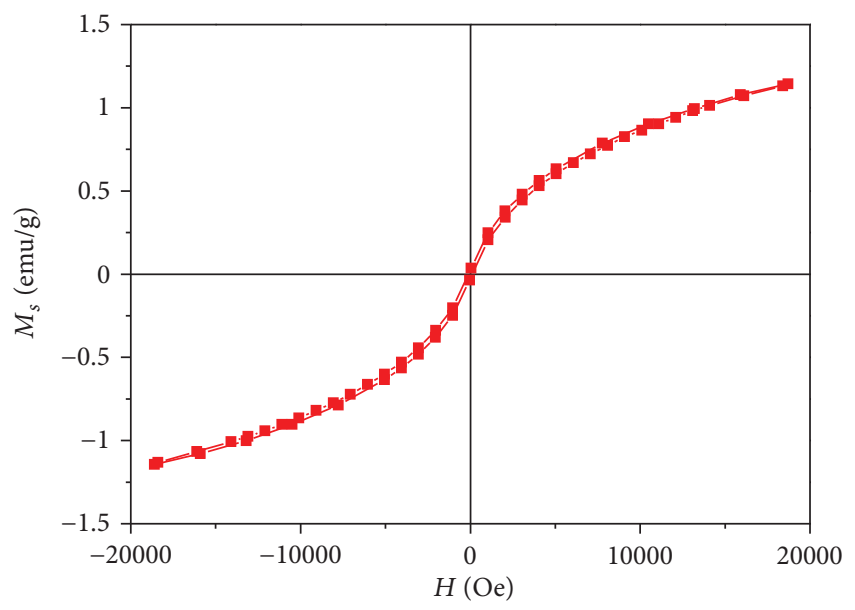

FIGURE 5: Magnetization curve of magnetic mesoporous FePt/C composites measured at room temperature. black points (FePt nanoparticles) are uniformly distributed in the entire particles. Furthermore, most of FePt nanoparticles are distributed in the carbon walls, and the sizes are similar to the diameters of carbon walls, which suggest these FePt nanoparticles are embedded in the carbon walls. It can be understood that polyfurfuryl alcohol was confined in the channels of SBA-15 template, and Fe and Pt precursors were highly dispersed within the polyfurfuryl alcohol framework. During carbonization process, the cross-linked polyfurfuryl alcohol converted into compact carbon and fully filled in the channels of SBA-15 template, resulting into no space between silica wall and carbon rod for the growth of FePt nanoparticles. As a result, FePt nanoparticles only can grow in the carbon framework.

Figure 4 shows the nitrogen adsorption-desorption isotherm and the corresponding pore size distribution of magnetic mesoporous $\mathrm{FePt} / \mathrm{C}$ composites. The isotherm curve is of type IV with a marked leap in the adsorption branch between relative pressures $P / P_{0}$ of 0.42 and 0.7 , which is typical for mesoporous materials. It suggests that the ordered mesoporous structure has been kept after the embedding of FePt nanoparticles. The specific surface area is $1244 \mathrm{~m}^{2} / \mathrm{g}$ calculated from the linear part of the BET (Brunauer-Emmett-Teller) plot, and the single point adsorption total volume at $P / P_{0}=0.90$ and micropore volume calculated from $t$-plot method are 1.396 and $0.553 \mathrm{~cm}^{3} / \mathrm{g}$, respectively. The corresponding pore size distribution curve calculated from adsorption branch by the BJH (BarrettJoyner-Halenda) method shows a narrow pore size distribution peaked at $4.93 \mathrm{~nm}$ (inset of Figure 4), allowing small biomolecules to adsorb into the channels of magnetic mesoporous $\mathrm{FePt} / \mathrm{C}$ composites.

Figure 5 shows the magnetization curve of mesoporous $\mathrm{FePt} / \mathrm{C}$ composites measured at room temperature. The magnetization strength of mesoporous $\mathrm{FePt} / \mathrm{C}$ composites is $1.14 \mathrm{emu} / \mathrm{g}$ at $20 \mathrm{~K} \mathrm{Oe}$, and almost no hysteresis loop can be observed in the magnetization curve, which suggests that mesoporous $\mathrm{FePt} / \mathrm{C}$ composites have superparamagnetic property. This may be due to that most of FePt nanoparticles 


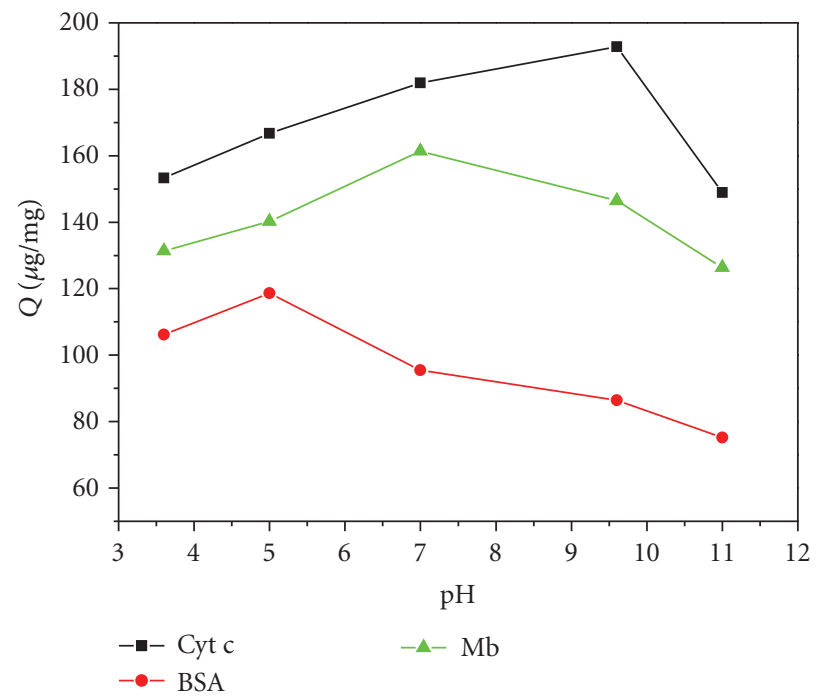

(a)

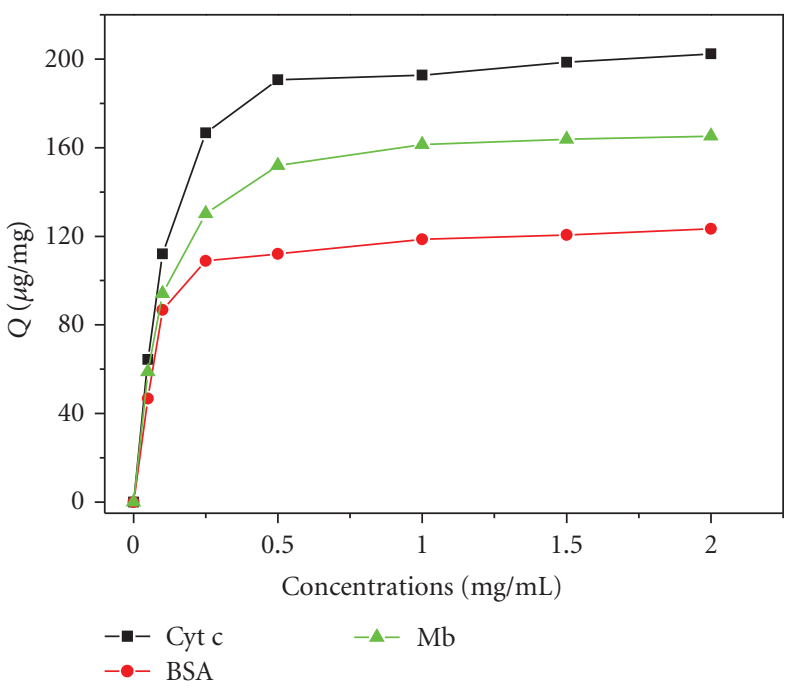

(b)

FIGURE 6: (a) the adsorption capacities of $\mathrm{Cyt} \mathrm{c}, \mathrm{Mb}$, and BSA on magnetic mesoporous FePt/C composites with different solution pH ranging from 3.6 to 10.8 at protein concentration of $1.0 \mathrm{mg} / \mathrm{mL}$; (b) the adsorption curves of $\mathrm{Cyt} \mathrm{c}, \mathrm{Mb}$, and BSA on magnetic mesoporous FePt/C composites with the solution at a $\mathrm{pH}$ equal to the $\mathrm{pI}$ of each protein $(\mathrm{pI}=9.8$ for $\mathrm{Cyt} \mathrm{c}, \mathrm{pI}=7.2$ for $\mathrm{Mb}$, and $\mathrm{pI}=4.8$ for $\mathrm{BSA}$ ).

are embedded in the carbon walls and their particle sizes are small enough to exhibit the superparamagnetic behavior. Therefore, these magnetic mesoporous FePt/C composites could be used as magnetically separable adsorbents.

In order to evaluate the ability of magnetic mesoporous $\mathrm{FePt} / \mathrm{C}$ composites to adsorb biomolecules, we investigated the protein adsorption on magnetic mesoporous $\mathrm{FePt} / \mathrm{C}$ composites. Three different globular proteins, cytochrome c (Cyt c), myoglobin (Mb), and bovine serum albumin (BSA) were used as model proteins to study the adsorption capacities on magnetic mesoporous $\mathrm{FePt} / \mathrm{C}$ composites. Figure 6(a) shows the adsorption capacities of Cyt c, Mb, and $\mathrm{BSA}$ on magnetic mesoporous $\mathrm{FePt} / \mathrm{C}$ composites with different solution $\mathrm{pH}$ ranging from 3.6 to 10.8 at protein concentration of $1.0 \mathrm{mg} / \mathrm{mL}$. It can be observed that magnetic mesoporous $\mathrm{FePt} / \mathrm{C}$ composites have the highest adsorption capacity for Cyt $\mathrm{c}$ and the lowest adsorption capacity for BSA, respectively. It has been accepted that the relative size of the protein molecules with respect to the channel diameter of mesoporous materials influences directly the protein adsorption capacity [28]. In this work, the peak pore size of magnetic mesoporous $\mathrm{FePt} / \mathrm{C}$ composites $\left(D_{p}\right)$ is $4.93 \mathrm{~nm}$, but the proteins have different molecular sizes. The dimensions of Cyt c, Mb, and BSA are around $2.6 \times$ $3.2 \times 3.0 \mathrm{~nm}, 2.9 \times 3.6 \times 6.4 \mathrm{~nm}$, and $5.5 \times 5.6 \times 12.0 \mathrm{~nm}$, respectively. As a result, the smallest Cyt c proteins could be adsorbed in the channels of magnetic mesoporous FePt/C composites more than the larger $\mathrm{Mb}$ and BSA proteins. On the other hand, the highest adsorption capacity for each protein can be found at a $\mathrm{pH}$ equal to the isoelectric point (pI) of each protein ( $\mathrm{pI}=9.8$ for Cyt $\mathrm{c}, \mathrm{pI}=7.2$ for $\mathrm{Mb}$, and $\mathrm{pI}=4.8$ for BSA). The adsorption of proteins is typically determined by electrostatic and hydrophobic interactions, and the cohesive attraction and repulsion of the amino acids present in the protein molecules [29]. Near the $\mathrm{pI}$, the net charge of proteins is around zero, and thus the hydrophobic interactions between the protein molecules and magnetic mesoporous $\mathrm{FePt} / \mathrm{C}$ composites (carbon rods are hydrophobic) dominate the protein adsorption ability on magnetic mesoporous $\mathrm{FePt} / \mathrm{C}$ composites. Furthermore, there is no repulsion between amino acid residues on the surface of adsorbed protein molecules near the pI [29], resulting into that the protein molecules are more densely packed on the surface of magnetic mesoporous $\mathrm{FePt} / \mathrm{C}$ composites. Therefore, the adsorption capacities of Cyt c, Mb, and BSA are highest near the pI of each protein, respectively. The adsorption capacities of Cyt $\mathrm{c}, \mathrm{Mb}$, and BSA are reduced below and above the pI, which could be ascribed to the expansion of the effective molecular diameter of each protein since strong repulsive forces between the amino acid residues of the molecule are present below and above the pI, and more space is needed for the expanded protein molecules.

Figure 6(a) shows the adsorption curves of Cyt c, Mb, and BSA on magnetic mesoporous $\mathrm{FePt} / \mathrm{C}$ composites with the solution at a pH equal to the $\mathrm{pI}$ of each protein. Each adsorption curve shows a sharp initial rise and a following steady stage, suggesting a high affinity between the protein molecules and the surface of mesoporous $\mathrm{FePt} / \mathrm{C}$ composites at the initial stage. The saturation adsorption capacities on magnetic mesoporous $\mathrm{FePt} / \mathrm{C}$ composites for $\mathrm{Cyt} \mathrm{c}, \mathrm{Mb}$, and BSA are around 200,162 , and $121 \mu \mathrm{g} / \mathrm{mg}$, respectively, indicating that magnetic mesoporous FePt/C composites exhibit superior protein adsorption ability. The saturation adsorption for each protein can be reached at concentrations above $0.5 \mathrm{mg} / \mathrm{mL}$, which confirmed that the adsorption capacities of each protein on magnetic mesoporous $\mathrm{FePt} / \mathrm{C}$ composites in Figure 6(a) reached the saturation adsorption. Therefore, magnetic mesoporous $\mathrm{FePt} / \mathrm{C}$ composites have potential as 
magnetically separable adsorbent for biomolecules separation.

\section{Conclusion}

Magnetic mesoporous $\mathrm{FePt} / \mathrm{C}$ composites with $\mathrm{FePt}$ nanoparticles embedded in carbon walls were successfully prepared using a simple cocasting method. Furfuryl alcohol, $\mathrm{Fe}(\mathrm{acac})_{3}$, and $\mathrm{Pt}(\mathrm{acac})_{2}$ that were simultaneously incorporated into the channels of SBA-15 template made the Fe and Pt precursors be highly dispersed within the polyfurfuryl alcohol framework after polymerization process. During carbonization process, the cross-linked polyfurfuryl alcohol is converted into compact carbon and fully filled in the channels of SBA-15 template, resulting into the embedding of FePt nanoparticles in carbon walls. This cocasting method made the preparation procedure simpler and saved the preparation time. The results indicated that $\mathrm{FePt} / \mathrm{C}$ composites have ordered mesoporous structure with high surface area of $1244 \mathrm{~m}^{2} / \mathrm{g}$, narrow mesopore size distribution peaked at $4.93 \mathrm{~nm}$, and superparamagnetic behavior $\left(M_{s}=1.14 \mathrm{emu} / \mathrm{g}\right)$. By using Cyt $\mathrm{c}, \mathrm{Mb}$, and BSA as model proteins, the adsorption capacities of mesoporous $\mathrm{FePt} / \mathrm{C}$ composites can reach ca. 200, 162, and $121 \mu \mathrm{g} / \mathrm{mg}$, respectively. Therefore, these magnetic mesoporous FePt/C composites have potential as magnetically separable adsorbents for biomolecules separation.

\section{Acknowledgments}

The authors gratefully acknowledge the support by the Program for Professor of Special Appointment (Eastern Scholar) at Shanghai Institutions of Higher Learning, National Natural Science Foundation of China (no. 51102166) and Shanghai Pujiang Program (no. 11PJ1407300), Innovation Program of Shanghai Municipal Education Commission (no. 12ZZ140), and Key Project of Chinese Ministry of Education (no. 212055). The authors declare that we do not have any relation with the instrument manufacturers mentioned in "Characterization Section".

\section{References}

[1] R. Ryoo, S. H. Joo, M. Kruk, and M. Jaroniec, "Ordered mesoporous carbons," Advanced Materials, vol. 13, pp. 677-681, 2001.

[2] Y. Chi, W. Geng, L. Zhao et al., "Comprehensive study of mesoporous carbon functionalized with carboxylate groups and magnetic nanoparticles as a promising adsorbent," Journal of Colloid and Interface Science, vol. 369, pp. 366-372, 2012.

[3] Y. Yin, S. Zhou, C. Min, and L. Wu, "Preparation of rattle-type magnetic mesoporous carbon spheres and their highly efficient adsorption and separation," Journal of Colloid and Interface Science, vol. 361, no. 2, pp. 527-533, 2011.

[4] G. Gupta, D. A. Slanac, P. Kumar et al., "Highly stable $\mathrm{Pt} /$ ordered graphitic mesoporous carbon electrocatalysts for oxygen reduction," Journal of Physical Chemistry C, vol. 114, no. 24, pp. 10796-10805, 2010.
[5] T. Chen, T. Wang, D. J. Wang et al., "Synthesis of ordered largepore mesoporous carbon for $\mathrm{Cr}(\mathrm{VI})$ adsorption," Materials Research Bulletin, vol. 46, no. 9, pp. 1424-1430, 2011.

[6] B. You, J. Yang, Y. Q. Sun, and Q. D. Su, "Easy synthesis of hollow core, bimodal mesoporous shell carbon nanospheres and their application in supercapacitor," Chemical Communications, vol. 47, pp. 12364-12366, 2011.

[7] K. K. R. Datta, A. Vinu, S. Mandal, S. Al-Deyab, J. P. Hill, and K. Ariga, "Base-selective adsorption of nucleosides to pore-engineered nanocarbon, carbon nanocage," Journal of Nanoscience and Nanotechnology, vol. 11, pp. 3959-3964, 2011.

[8] A. Vinu, M. Miyahara, V. Sivamurugan, T. Mori, and K. Ariga, "Large pore cage type mesoporous carbon, carbon nanocage: a superior adsorbent for biomaterials," Journal of Materials Chemistry, vol. 15, no. 48, pp. 5122-5127, 2005.

[9] M. Feng, A. B. Morales, T. Beugeling et al., "Adsorption of high density lipoproteins (HDL) on solid surfaces," Journal of Colloid and Interface Science, vol. 177, no. 2, pp. 364-371, 1996.

[10] Z. X. Wu, W. Li, P. A. Webley, and D. Y. Zhao, "General and controllable synthesis of novel mesoporous magnetic iron oxide@carbon encapsulates for efficient arsenic removal," Advanced Materials, vol. 24, pp. 485-491, 2012.

[11] J. S. Becker, O. R. T. Thomas, and M. Franzreb, "Protein separation with magnetic adsorbents in micellar aqueous twophase systems," Separation and Purification Technology, vol. 65, no. 1, pp. 46-53, 2009.

[12] Y. Zhai, Y. Dou, X. Liu, B. Tu, and D. Zhao, "One-pot synthesis of magnetically separable ordered mesoporous carbon," Journal of Materials Chemistry, vol. 19, no. 20, pp. 3292-3300, 2009.

[13] E. Kang, H. Jung, J. G. Park et al., "Block copolymer directed one-pot simple synthesis of L10-phase FePt nanoparticles inside ordered mesoporous aluminosilicate/carbon composites," ACS Nano, vol. 5, no. 2, pp. 1018-1025, 2011.

[14] S. Tanaka, N. Nishiyama, Y. Egashira, and K. Ueyama, "Synthesis of ordered mesoporous carbons with channel structure from an organic-organic nanocomposite "' Chemical Communications, no. 16, pp. 2125-2126, 2005.

[15] Y. Meng, D. Gu, F. Zhang et al., "Ordered mesoporous polymers and homologous carbon frameworks: amphiphilic surfactant templating and direct transformation," Angewandte Chemie, vol. 44, pp. 7053-7059, 2005.

[16] F. Zhang, Y. Meng, D. Gu et al., "A facile aqueous route to synthesize highly ordered mesoporous polymers and carbon frameworks with Ia3d bicontinuous cubic structure," Journal of the American Chemical Society, vol. 127, no. 39, pp. 13508-13509, 2005.

[17] A. H. Lu, W. Schmidt, N. Matoussevitch et al., "Nanoengineering of a magnetically separable hydrogenation catalyst," Angewandte Chemie, vol. 43, no. 33, pp. 4303-4306, 2004.

[18] Z. Wang, X. Liu, M. Lv, and J. Meng, "Simple synthesis of magnetic mesoporous $\mathrm{FeNi} /$ carbon composites with a large capacity for the immobilization of biomolecules," Carbon, vol. 48, no. 11, pp. 3182-3189, 2010.

[19] X. Dong, H. Chen, W. Zhao, X. Li, and J. Shi, "Synthesis and magnetic properties of mesostructured $\gamma$-Fe 2O3/carbon composites by a co-casting method," Chemistry of Materials, vol. 19, no. 14, pp. 3484-3490, 2007.

[20] J. Lee, S. Jin, Y. Hwang, J. G. Park, H. M. Park, and T. Hyeon, "Simple synthesis of mesoporous carbon with magnetic nanoparticles embedded in carbon rods," Carbon, vol. 43, no. 12, pp. 2536-2543, 2005. 
[21] L. Guo, S. Zeng, J. Li et al., "An easy co-casting method to synthesize mesostructured carbon composites with high magnetic separability and acid resistance," New Journal of Chemistry, vol. 33, no. 9, pp. 1926-1931, 2009.

[22] I. S. Park, M. Choi, T. W. Kim, and R. Ryoo, "Synthesis of magnetically separable ordered mesoporous carbons using furfuryl alcohol and cobalt nitrate in a silica template," Journal of Materials Chemistry, vol. 16, no. 33, pp. 3409-3416, 2006.

[23] S. Sun, "Recent advances in chemical synthesis, self-assembly, and applications of FePt nanoparticles," Advanced Materials, vol. 18, no. 4, pp. 393-403, 2006.

[24] G. Gupta, M. N. Patel, D. Ferrer et al., "Stable ordered FePt mesoporous silica catalysts with high loadings," Chemistry of Materials, vol. 20, no. 15, pp. 5005-5015, 2008.

[25] E. Kockrick, P. Krawiec, W. Schnelle et al., "Space-confined formation of fept nanoparticles in ordered mesoporous silica SBA-15," Advanced Materials, vol. 19, no. 19, pp. 3021-3026, 2007.

[26] Y. Zhu, E. Kockrick, S. Kaskel, T. Ikoma, and N. Hanagata, "Nanocasting route to ordered mesoporous carbon with FePt nanoparticles and its phenol adsorption property," Journal of Physical Chemistry C, vol. 113, no. 15, pp. 5998-6002, 2009.

[27] A. Sayari, B. H. Han, and Y. Yang, "Simple synthesis route to monodispersed SBA-15 silica rods," Journal of the American Chemical Society, vol. 126, no. 44, pp. 14348-14349, 2004.

[28] L. C. Sang, A. Vinu, and M. O. Coppens, "General description of the adsorption of proteins at their iso-electric point in nanoporous materials," Langmuir, vol. 27, pp. 13828-13837, 2011.

[29] A. Vinu, C. Streb, V. Murugesan, and M. Hartmann, "Adsorption of cytochrome c on new mesoporous carbon molecular sieves," Journal of Physical Chemistry B, vol. 107, no. 33, pp. 8297-8299, 2003. 

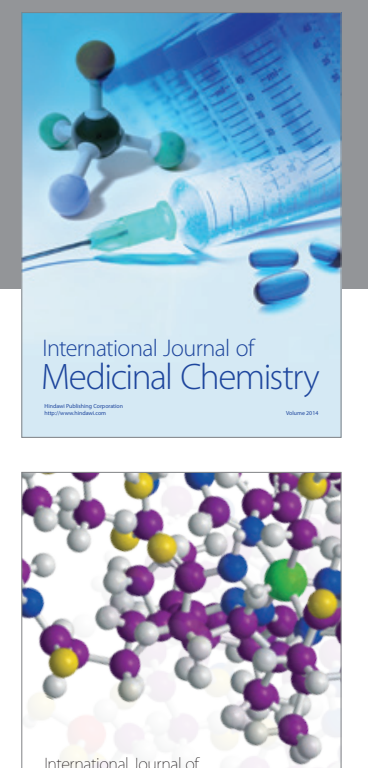

\section{Carbohydrate} Chemistry

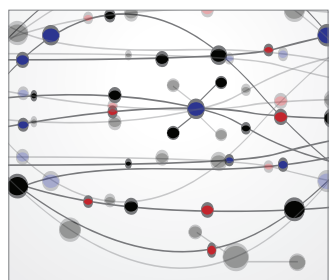

The Scientific World Journal
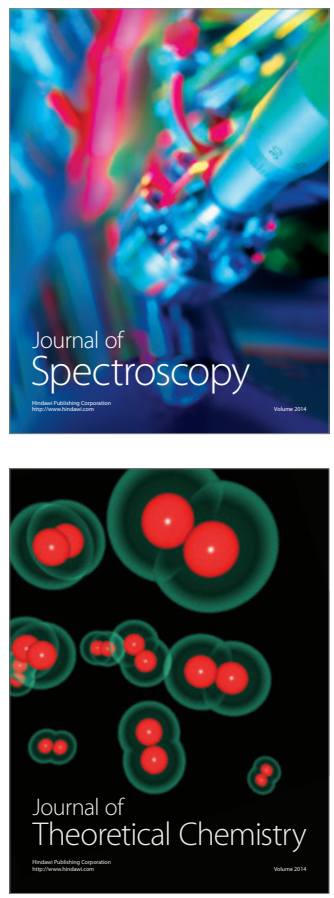
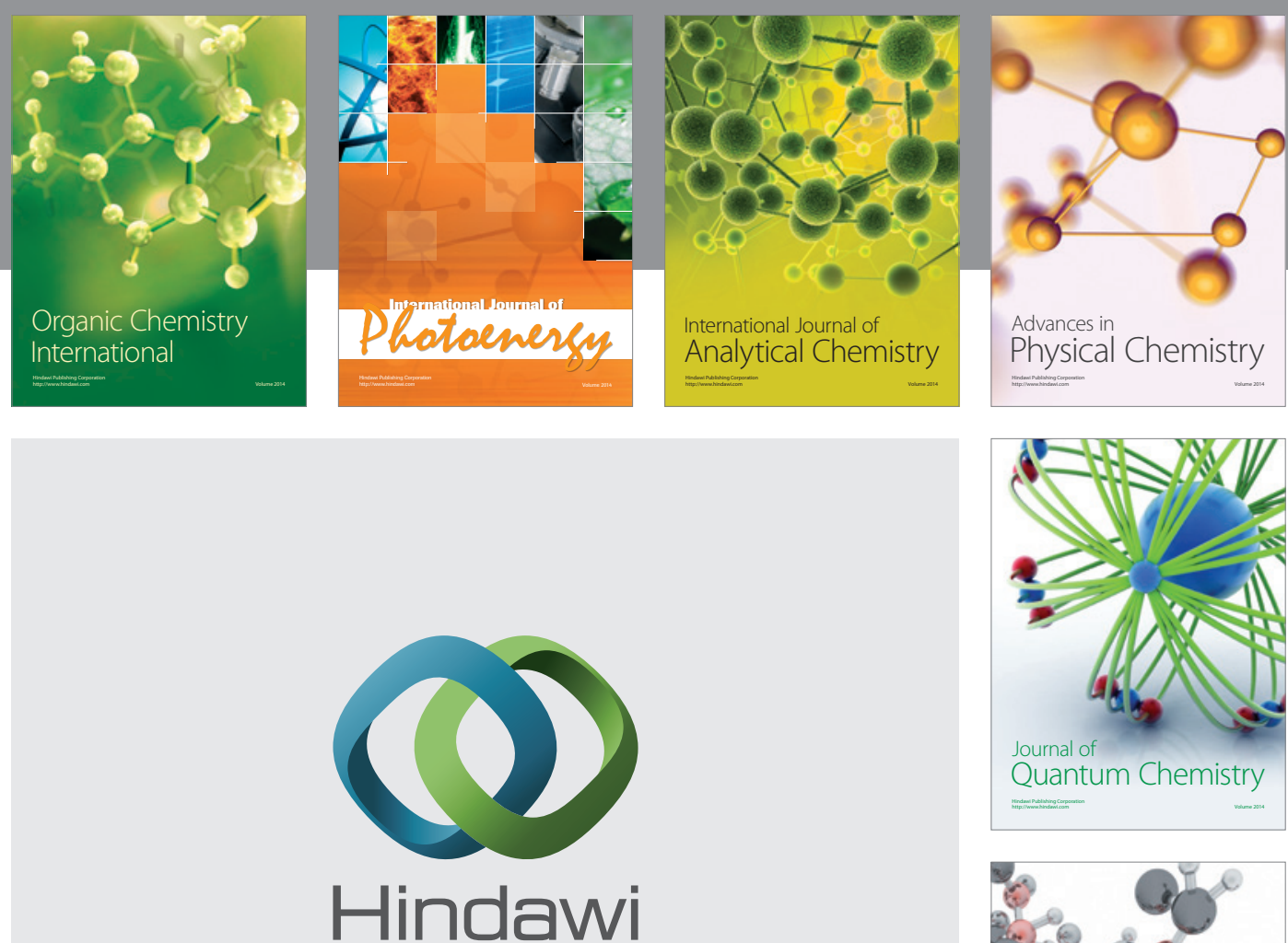

Submit your manuscripts at

http://www.hindawi.com

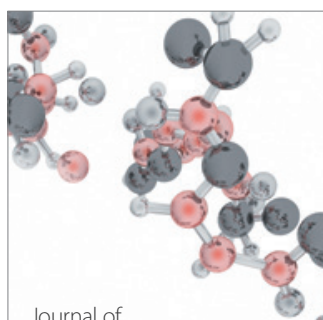

Analytical Methods

in Chemistry

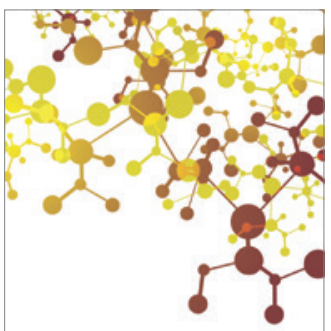

Journal of

Applied Chemistry

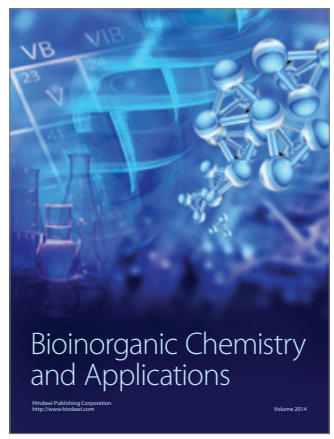

Inorganic Chemistry
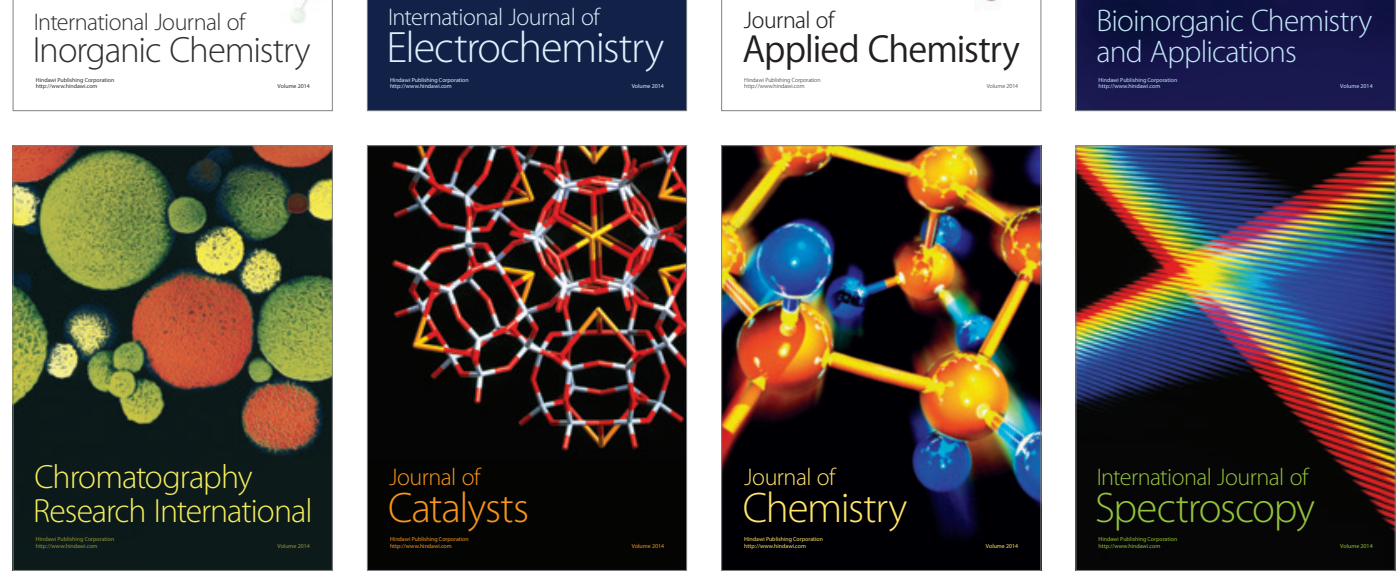